\title{
Universiteit
}

Leiden

The Netherlands

\section{Highlights of the Workshop Discussions}

Cotula, L.; Mathieu, P.; Hatcher, J.; Ubink, J.M.; Meene, I.S. van de; Cotula, J.; Mathieu, P.

\section{Citation}

Cotula, L., Mathieu, P., Hatcher, J., Ubink, J. M., \& Meene, I. S. van de. (2008). Highlights of the Workshop Discussions. In J. Cotula \& P. Mathieu (Eds.), Legal Empowerment in Practice: Using Legal Tools to Secure Land Rights in Africa (pp. 133-140). Londen, Rome: IIED, FAO. Retrieved from https://hdl.handle.net/1887/32310

Version: $\quad$ Not Applicable (or Unknown)

License:

Downloaded from: $\quad$ https://hdl.handle.net/1887/32310

Note: To cite this publication please use the final published version (if applicable). 


\section{Legalempowerment in practice}

Using legal tools to secure land rights in Africa
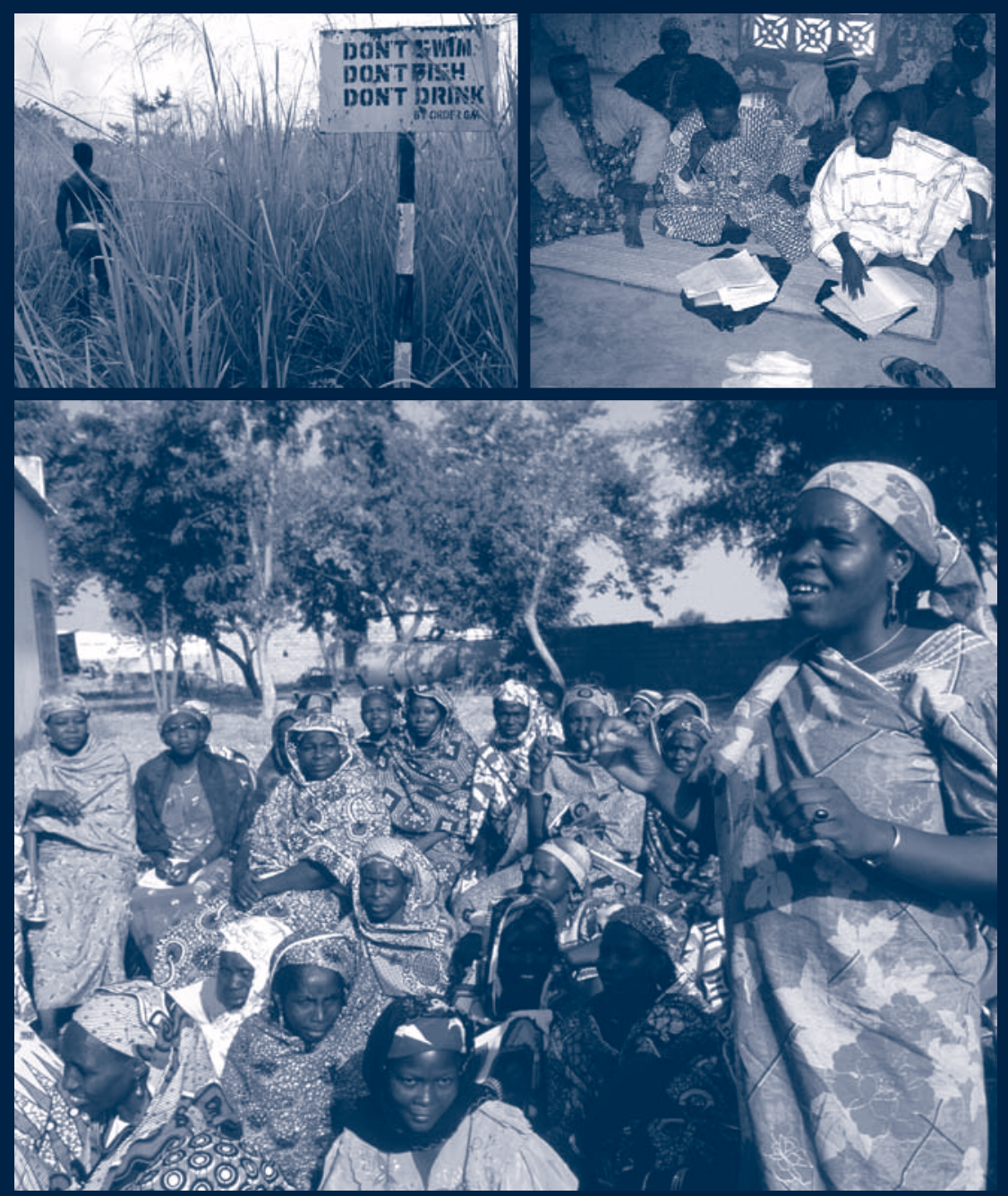

Edited by Lorenzo Cotula and Paul Mathieu
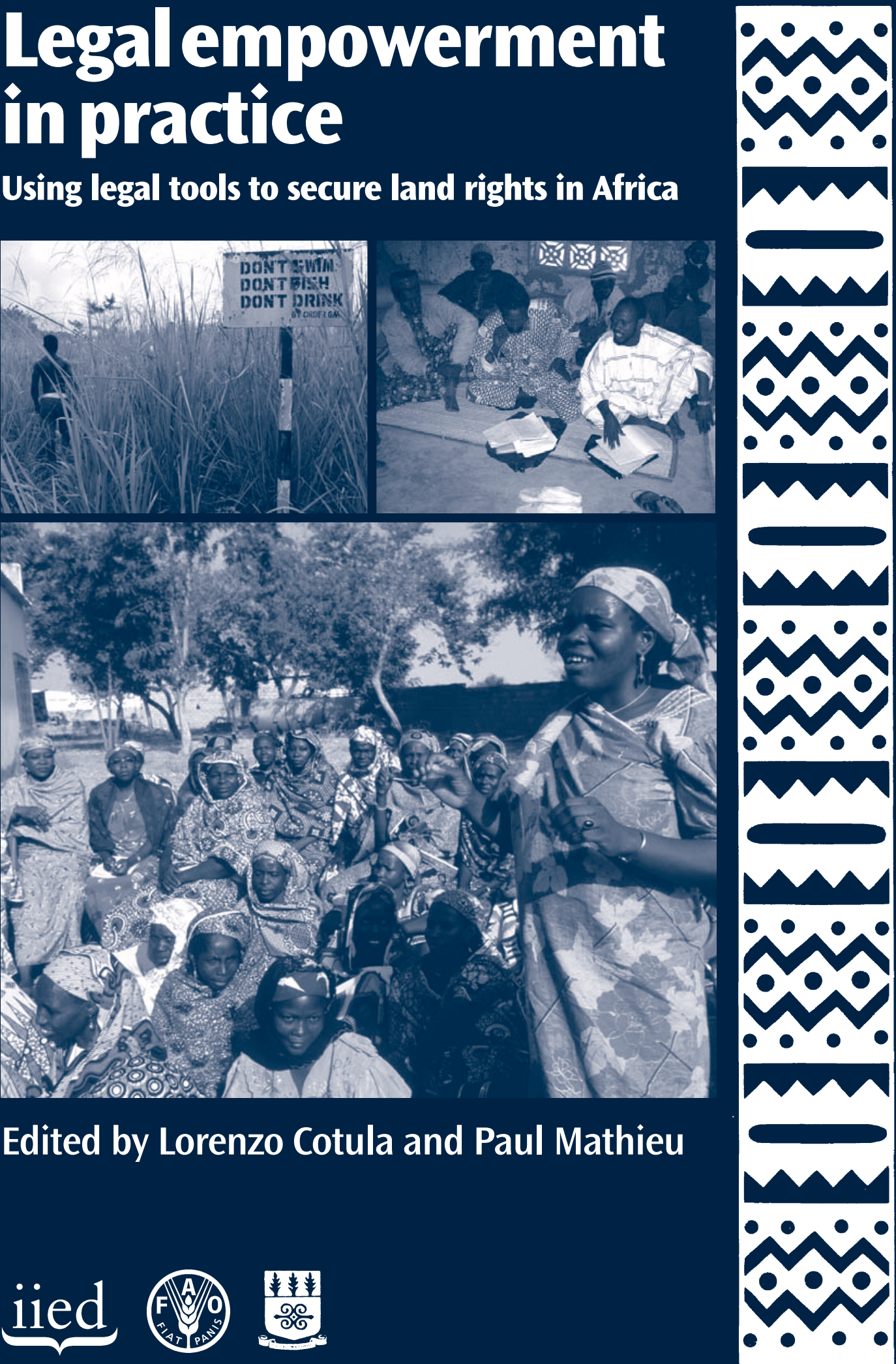


\section{Legalempowerment in practice}

Using legal tools to secure land rights in Africa

Highlights from the international workshop "Legal empowerment for securing land rights" Accra, 13th-14th March 2008

Edited by Lorenzo Cotula and Paul Mathieu
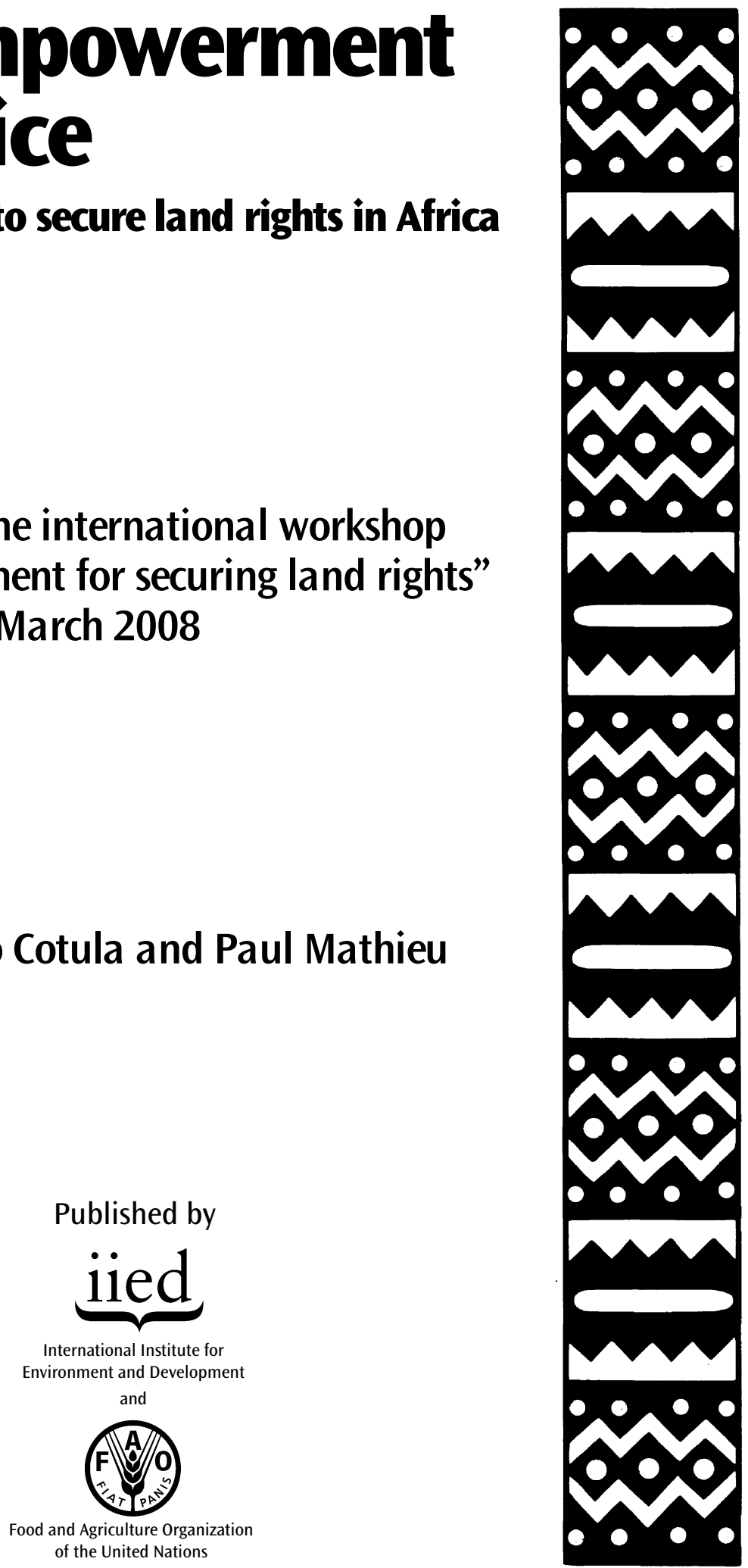


\section{LEGAL EMPOWERMENT IN PRACTICE USING LEGAL TOOLS TO SECURE LAND RIGHTS IN AFRICA}

\section{Edited by Lorenzo Cotula and Paul Mathieu}

All rights reserved. Reproduction and dissemination of material in this information product for educational or other non-commercial purposes are authorised without any prior written permission from the copyright holders provided the source is fully acknowledged. Reproduction of material in this information product for resale or other commercial purposes is prohibited without written permission of the copyright holders. Applications for such permission should be addressed to the Chief, Electronic Publishing Policy and Support Branch, Communication Division, FAO, Viale delle Terme di Caracalla, 00100 Rome, Italy or by e-mail to copyright@fao.org

(C) FAO and IIED, 2008

For copies of this publication, contact IIED. Email: newbooks@iied.info IIED Order No: 12552IIED

Citation: Cotula, L., Mathieu, P. (Eds), 2008, LEGAL EMPOWERMENT IN PRACTICE: USING LEGAL TOOLS TO SECURE LAND RIGHTS IN AFRICA, IIED, London. ISBN: 978-1-84369-703-9

Cover photos: Top left: Ahansonyewodea Village, Nr. Obuasi, Ashanti region, Ghana. A cautionary sign, erected by the AngloGold Ashanti gold mining corporation, warns local people that the water around the Jimiso dam is contaminated. Top right: Training of paralegals and pastoral organisations in Mali, organised by EVEIL (C) Boubacar Ba. Main: Women's co-operative community meeting, North Cameroon (C) Giacomo Pirozzi / Panos Pictures.

Design: Smith+Bell (www.smithplusbell.com)

Printing: Russell Press (www.russellpress.com)

Printed on: Greencoat Velvet 200 gsm and Greencoat Velvet $100 \mathrm{gsm}$

The designations employed and the presentation of material in this publication do not imply the expression of any opinion whatsoever on the part of the Food and Agriculture Organization of the United Nations concerning the legal status of any country, territory, city or area or of its authorities, or concerning the delimitation of its frontiers or boundaries. The mention of specific companies or products of manufacturers, whether or not these have been patented, does not imply that these have been endorsed or recommended by FAO in preference to others of a similar nature that are not mentioned. The views expressed herein are those of the authors and do not necessarily represent those of FAO. 


\section{CONTENTS}

1. INTRODUCTION

Lorenzo Cotula, Paul Mathieu and Dominic Ayine

2. LEGAL EMPOWERMENT TO SECURE LAND RIGHTS DEFINING THE CONCEPT

Lorenzo Cotula

3. LEGAL EMPOWERMENT IN PRACTICE TO SECURE THE LAND RIGHTS OF THE POOR - A SHORT CONCEPT NOTE

Paul Mathieu

4. USING THE LAW AS A TOOL TO SECURE THE LAND RIGHTS OF INDIGENOUS COMMUNITIES IN SOUTHERN CAMEROON

Samuel Nguiffo and Robinson Djeukam

5. PARALEGALS AS AGENTS OF LEGAL EMPOWERMENT IN THE BANKASS AREA OF MALI

Boubacar Ba

6. LEGAL EMPOWERMENT TO SECURE AND USE LAND AND RESOURCE RIGHTS IN MOZAMBIQUE

Carlos Serra Jr and Christopher Tanner

7. LAND RIGHTS INFORMATION CENTRES IN UGANDA Rita H. Aciro-Lakor.

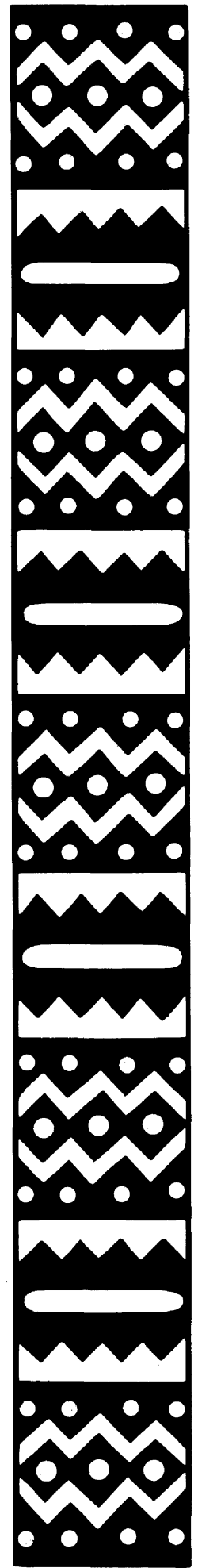


8. PARALEGALS AND COMMUNITY OVERSIGHT BOARDS IN SIERRA LEONE Simeon Koroma

9. LEGAL LITERACY TRAINING IN THE THIÈS REGION OF SENEGAL

Yahya Kane

10. AWARENESS-RAISING AND PUBLIC INTEREST LITIGATION FOR MINING COMMUNITIES IN TANZANIA

Ednah Mndeme

11. HELPING COMMUNITIES GAIN RECOGNITION AS LEGAL ENTITIES:

THE EXPERIENCE OF THE CHIBHEMEME EARTH HEALING ASSOCIATION IN ZIMBABWE

Mutuso Dhliwayo.

12. CHALLENGING THE CONSTITUTIONALITY OF LAND LEGISLATION IN SOUTH AFRICA

Aninka Claasens.

13. LEGAL CLINICS AND PARTICIPATORY LAW-MAKING FOR INDIGENOUS PEOPLES IN THE REPUBLIC OF CONGO

Lilian Laurin Barros

14. PROCEDURAL RIGHTS: INCLUSION IN DECISION-MAKING PROCESSES RELATING TO LAND AND NATURAL RESOURCES Linda Siegele.

15. HIGHLIGHTS OF THE WORKSHOP DISCUSSIONS

Lorenzo Cotula, Paul Mathieu, Jeffrey Hatcher, Janine Ubink and Ineke van de Meene

REFERENCES

WORKSHOP PROGRAMME 146

LIST OF PARTICIPANTS 148 
15. HIGHLIGHTS OF THE WORKSHOP DISCUSSIONS

Lorenzo Cotula, Paul Mathieu, Jeffrey Hatcher, Janine Ubink and Ineke van de Meene

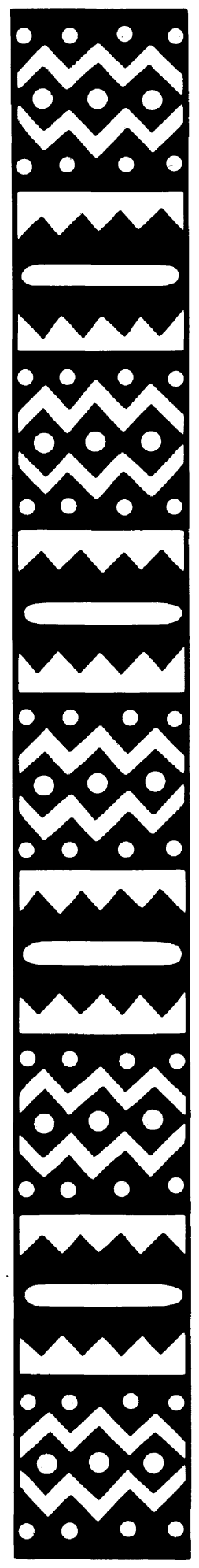


Over the two days of workshop discussions, participants shared a wealth of innovative experiences regarding legal empowerment to secure land rights. Some have been written up and included in previous chapters of this report, others have not - partly because some are still at an early stage of the process.

Overall, the experiences shared and discussed at the workshop highlight the great diversity of possible routes to legal empowerment, which can involve a range of approaches, tools and methods (from legal literacy training to litigation) as well as target groups (pastoralists, indigenous peoples, women and others). This diversity of tools and target groups is the natural consequence of the variety of contexts concerned. There is no blueprint approach to legal empowerment, as different local problems and needs require different solutions.

Despite this diversity, a common characteristic of successful legal empowerment initiatives is the ability to work creatively with the opportunities offered by applicable law. Although much remains to be done in many countries to establish national legal frameworks that facilitate secure land rights for poorer groups, recent waves of law reform in several countries have created or improved opportunities for securing local land rights.

Creative use of legal pluralism can expand these opportunities. Where national land legislation is lacking, it may be possible to rely on constitutional provisions or international standards. These standards may include international human rights and environmental treaties (see the work on "procedural rights" carried out by FIELD), or the social and environmental standards applied by lending institutions involved in large-scale projects (such as the World Bank in the Chad-Cameroon oil pipeline project, and the work spearheaded by CED to defend indigenous peoples' resource rights in Cameroon).

Similarly, while reliance on "customary" systems may be effective in resolving local disputes where such systems are perceived as legitimate on the ground, reliance on constitutional norms can provide a legal entry point to challenge discriminatory or unaccountable customary systems or national legislation entrenching them (see, for instance, the constitutionality challenge brought by the Legal Resources Centre in South Africa). 
However, disadvantaged groups tend to be unaware of the opportunities offered by national law or international frameworks. Raising citizens' awareness of their rights and the procedures for securing them is therefore a necessary first step in legal empowerment processes. Most, if not all, of the experiences discussed at the workshop had an element of legal awareness raising. The tools used to do this vary greatly - from the radio programmes, theatre plays and village debates organised by the Land Rights Information Centres in Uganda, to the development and implementation of legal literacy trainings targeting elected local councillors and the local population at large in Senegal, through to working with paralegals in contexts as diverse as Sierra Leone, Namibia, Congo Brazzaville, Mozambique, Mali, Ghana, Cameroon and Uganda.

Awareness of rights and how to use them can increase social self-confidence and capacity, leading to more assertive claims and the enforcement and protection of rights. Information is power, and awareness raising is a necessary part of legal empowerment. Yet simply providing information may not be sufficient to promote legal empowerment. Even where people are aware of their rights, they may lack the know-how and resources to go through the procedures provided by the law to exercise and enforce those rights. They may also find it difficult to counter abuses of the law or inadequate implementation by other parties, such as government officials and private companies.

This means that other types of support are needed too. This may include helping local groups establish legal entities to engage with government and the private sector (see, for instance, the work of ZELA in Zimbabwe and Centro Terra Viva in Mozambique); helping local groups obtain certificates of village land rights, as illustrated by the work of the NGO CORDS in Tanzania; providing legal assistance to local groups in the consultation processes required by Mozambican law as a precondition for allocating resource rights to investors (see the work of Centro Terra Viva); and different forms of public interest litigation - from the court litigation used by the Centre for Public Interest Law to challenge uncompensated loss of land rights among local groups affected by mining in Ghana, to the constitutionality challenge against land legislation that undermines poorer groups' security of tenure brought by the Legal Resources Centre in South Africa. 
Producing and providing evidence of rights can also be an effective strategy. In some respects, new technologies have facilitated this task, as with the low-cost and easy-to-use technology employed by CED to map local resource rights in Cameroon. However, resource rights are embedded in complex contexts: who has which rights over what can be hotly contested, and as the Legal Resources Centre in South Africa found, producing evidence (on the content of customary law and rights, for example) can be a major challenge.

Legal empowerment is more than "legal work" - it is about tackling power asymmetries between competing land claims and authorities. Nor is it necessarily a win-win process. Some groups may see their power base eroded as weaker groups acquire greater voice, and are therefore likely to resist legal empowerment initiatives. Eveil's paralegal programme in Mali and the Land Rights Information Centres supported by the Uganda Land Alliance in Uganda both had to grapple with resistance from vested interests among village chiefs in Mali and certain government officials in Uganda. While creative use of "legal entry points" is important, it needs to be accompanied by social mobilisation, savvy identification and use of nonlegal "pressure points", and other ways of getting round resistance from vested interests. Strategic thinking and allocation of resources is necessary to ensure that actions leverage their efforts for maximum effect.

Among other things, effective social mobilisation is a function of the stakes involved and their implications for the community at large. Thus, the importance of land access and the widespread nature of land disputes were central in promoting local ownership of the Land Rights Information Centres in Uganda, while the existence of a common and immediate threat of eviction provided the basis for mobilising indigenous groups in Cameroon when a natural park was established in the context of the ChadCameroon oil pipeline project. Even the frustrating experience of challenging encroachment on pastoral lands in Tanzania showed that failed court litigation can act as a catalyst for social mobilisation.

However, it is also important to recognise the differentiation within local groups, which are not homogeneous and may have different interests and powers of negotiation. Several organisations are setting up community consultations (such as the Comptoir Juridique Junior in Congo-Brazzaville) or platforms for local debate (like CRAC-GRN in Niger) to help create common 
understanding, visions and solutions. These processes have increased local capacity by enlarging the space for negotiation with other parties and promoting greater cohesion and more effective regulation of intra-group relations.

Making effective use of non-legal pressure points is crucial in tackling power imbalances. For instance, understanding what motivates government officials and other actors, and making use of this incentive structure can be powerful tools. As a workshop participant from Mozambique noted, government officials tend not to like being "named and shamed" - so this can be used as a pressure point in legal empowerment processes.

Some of the experiences shared at the workshop show the importance of thinking "outside the box" to identify pressure points. Local problems may have international solutions, and the creative use of pressure points at different levels (local to national and international) can be an effective strategy.

For example, in the case from Cameroon, strategic action that made the most of the World Bank's involvement in the Chad-Cameroon pipeline project led to a park management plan that respected indigenous peoples' resource rights. This action involved putting pressure on the World Bank to pressure the government of Cameroon.

Similarly, the fact that the EU market accounts for a significant share of Ghanaian timber exports provided a pressure point for Civic Response and other NGOs pushing for an EU-Ghana Voluntary Partnership Agreement that respects local resource rights in international timber trade relations.

Dealing with vested interests does not necessarily mean taking a confrontational stance, as fostering better mutual understanding and dialogue can also play a crucial role. Strategies used by both Eveil and the Uganda Land Alliance to overcome resistance from local vested interests involved clarifying the nature and aims of their initiatives and promoting dialogue with their opponents. Depending on the sensitivity of the issues and the local political context, showing the government that actions are being taken to improve the system (rather than threaten or overthrow it) can also be a wise strategy - as exemplified by the work to get local communities recognised as legal entities carried out by ZELA in Zimbabwe. 
All the legal empowerment initiatives discussed at the workshop involved some form of external support from legal services organisations. While involving external actors can bring essential support to the empowerment process, it is the engagement of local groups that is the real driving force for change. Long-term commitment by legal services organisations and clear and effective communication between local groups and external actors are vital in building the level of trust needed for such initiatives to work; as is managing local expectations about what these initiatives can achieve, and respecting local sensitivities.

The Community Oversight Boards set up by Timap for Justice in Sierra Leone serve as a permanent buffer between Timap and the local communities, and have increased the transparency and accountability of Timap's paralegal programme. In the initiative spearheaded by CED in Cameroon, discussions about using mapping to secure local resource rights within a newly established natural park initially sparked concerns about boundary demarcation and related resource conflict; concerns that were resolved as the aim and focus of the exercise was clarified. Facilitating exchange visits and sharing real-life experiences with other groups that have already been through the proposed process may also help build trust and self-confidence - again, a strategy that was used in the case from Cameroon.

The experience from Uganda also shows that letting local groups themselves identify members to be trained as paralegals builds local ownership of the programme and trust in the impartiality and quality of the paralegals' work.

Beyond the trust established between local groups and legal services organisations, relations with other actors, particularly the government administration, are also important for the success of legal empowerment initiatives. In Uganda, the services provided by the Land Rights Information Centres are now appreciated and used by government officials. Similarly, winning over the government administration and/or customary authorities played an important role in the implementation of legal empowerment initiatives in Zimbabwe (ZELA) and Mali (with regard to the work of Eveil). On the other hand, obstruction by central or local government can raise important challenges for legal empowerment interventions (as with the LRC in South Africa). 


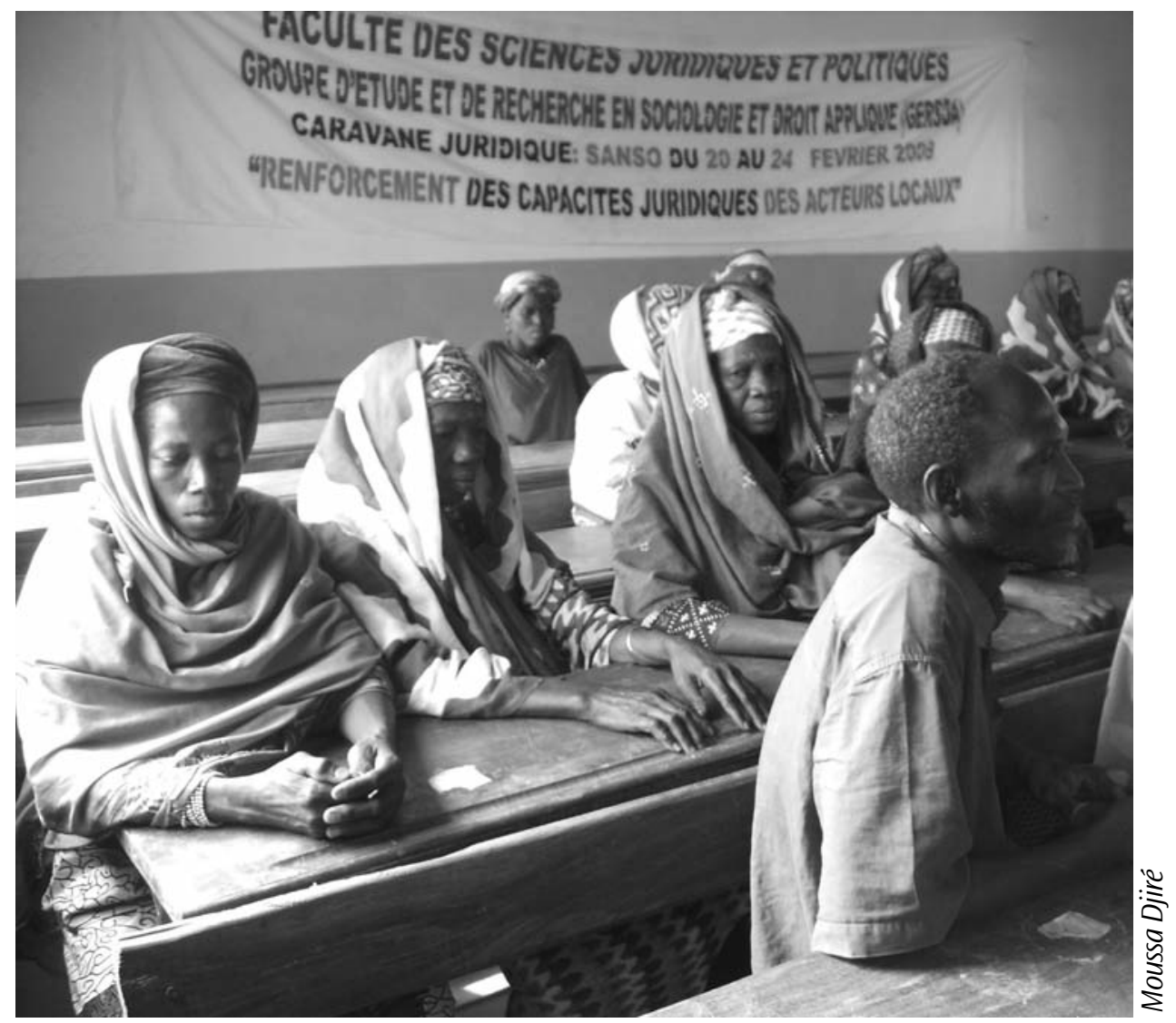

Legal caravans in Mali

A continuous local presence is important in building and maintaining trust, as is understanding the local context. This local presence may take a range of different forms - from the district-level Land Rights Information Centres in Uganda to "junior lawyers" in Cameroon and village-level paralegals in Mali. And when limited resources constrain the capacity to establish a local presence, innovative approaches such as the "legal caravans" being developed by GERSDA in Mali provide another way of raising local legal awareness. These caravans consult local groups to identify local capacity building needs, and hold awareness-raising sessions in affected villages. The sessions are spread over a few days, led by academic lawyers with support from their students. Rural radio is another way of reaching a broad and distant audience when resources are strained. 
Legal empowerment is inevitably a long-term process. Most initiatives depend on external funding from development agencies, which is typically tied to (relatively short-term) project funding cycles. This can undermine the sustainability of the initiatives, and the situation is exacerbated by the fact that successful legal empowerment initiatives tend to attract overwhelming local demand - which puts a strain on the limited staff and resources available.

Workshop discussions regarding the introduction of cost recovery as a way of measuring real local demand and ensuring longer-term sustainability highlighted the risk that this could make such initiatives inaccessible to poorer groups who cannot afford fees. Implementing means testing to differentiate between those who are able to pay and those who are not would be a challenge, and could lead to paying customers being prioritised and receiving better services.

It is important to be aware of the limits of these interventions in order to better tailor them to local needs and manage local expectations. Training community paralegals seems to be a particularly effective method of raising local people's awareness of their rights, helping with the procedural elements of securing land rights and monitoring changes and threats. However, it is also important not to create unrealistic expectations about what the paralegals can achieve on their own. As community members with only basic training in law, paralegals can face significant capacity challenges when called upon to handle complex issues or disputes.

Timap for Justice's experience of working with paralegals in Sierra Leone shows the need to provide regular support and supervision for communitybased paralegals, and for their training and work to focus on advising which other institutions and actors (including professional lawyers) to approach for particularly complex issues and situations.

Facilitating the exchange of experiences and lesson sharing among the legal services organisations and local groups involved in legal empowerment initiatives can help strengthen local self-confidence and capacity to engage in such initiatives, as well as sharpening the tools, approaches and methods used by legal services organisations. Lesson-sharing workshops, Internetbased "communities of practice", exchange visits and other mechanisms for exchange and mutual learning can all provide valuable support for local initiatives. 